Review scientific article Received 22.10.2018. Approved 15.12.2018.

\title{
RELATIONSHIP BETWEEN INNOVATION AND BUSINESS PERFORMANCE ${ }^{\mathrm{i} \text { ii }}$
}

The analysis of professional literature shows that many businesses measure innovation performance based on a combination of input and output indicators. The results of comparison confirmed that there are many concepts in innovation performance measurement, but they are not consistent. In scientific practice, there are also opinions that studies on indicators of innovation performance measurement are inadequate. The results indicate that most of the indicators are input-oriented and only few indicators are outputoriented. Businesses face difficulties when establishing a clear relationship between business innovation and its performance. When measuring innovation performance, there is a serious problem with a significant delay of the benefits of innovation and the complexity of the isolation of the role of innovation from other business activities with respect to the overall performance. Measuring innovative business performance can be achieved by financial indicators such as ROE, ROI and by non-financial indicators such as the number of new ideas, products, and so on. The paper aims to compare the development of innovation in the selected sector and the development of the sector's financial indicators for the identification of indicators whose development most closely corresponds to the development of innovation.

Keywords: Competitiveness, Evaluation, Innovation, Performance

* University of Economics in Bratislava, Faculty of Business Management, Bratislava, Slovakia, email: daniela.rybarova@euba.sk

* University of Economics in Bratislava, Faculty of Business Management, Bratislava, Slovakia, email: ingpeterstetka@gmail.com

*** University of Economics in Bratislava, Faculty of Business Management Bratislava, Slovakia, email: slavka.sagatova@euba.sk

This paper was prepared and presented in English language at the 30th International Scientific Conference on Economic and Social Development, at the Megatrend University in Belgrade, Serbia - 25 \& 26 May 2018.

ii This paper is an outcome of two complementary research projects: (1) „Zvyšovanie konkurencieschopnosti malých a stredných podnikov prostredníctvom zavádzania inovácií v globálnom hospodárskom prostredi“, VEGA no. 1/0857/16 - project share is 60\%; (2) „Výskum kognitívno-behaviorálnych determinantov difúzie produktových inovácii na trhoch EÜ“ VEGA no. $1 / 0876 / 17$ - project share is $40 \%$. 


\section{Introduction, theoretical basis and hypotheses}

Specialized literature defines innovation as a new or significantly improved product (product, service) introduced to the market, a new or significantly improved process, or a new organizational or marketing innovation introduced within the company. Innovations are based on the results of new technological developments, a new combination of existing technologies or utilization of other knowledge acquired by enterprise. Several studies defining the factors of innovation success have been developed and implemented (Hernardo and Szymanski ${ }^{1}$, Trommsdorff and Steinhoff ${ }^{2}$ ). Other approaches to assessing the success of innovation lie in an attempt to evaluate step by step the individual stages of a previously existing innovation process. The next group of authors propose to consider the effectiveness of innovation based on analogous indicators, such as in the evaluation of investment efficiency. These approaches seek the ways to evaluate the effects of innovation activities at company level.

The article is focused on the comparison of statistical processed reports on innovative activities of enterprises in various industries developed at the macro level with the development of the mean values of selected financial indicators in the surveyed sectors in order to identify the impact of innovation on company performance. Based on the results of the comparison, we will define the determinants showing the dependence of innovation activities.

\section{Methodology}

Business performance relates to the effectiveness of business operations and the success of the products and services on the market ${ }^{3}$. Way to gain a competitive advantage is inevitably connected with innovations. The innovations as the creation of something new, hitherto non-existent potentially always include the ability to attract customer's attention. Customers prefer novelty products and services as a strong buying incentive ${ }^{4}$. Successful innovation can bond customers' attention for longer periods, resulting in at least a temporary strengthening of the competitive position of the company. Maintaining and improving thus obtained position requires evaluation and strategical regulation of an innovative

1 Henard, D.H. - Szymanski, D.M. (2001): Why some new products are more successful than others. JMR, Journal of Marketing Research; Aug 2001; 38, 3; ABI/INFORM Global pg. 362

2 Trommsdorff, V. - Steinhoff, F. (2009): Marketing inovací. Praha: C.H. Beck, 2009. $291 \mathrm{s.}$

3 Markovič, P. - Rybárová, D. (2017): Bod indiferencie a optimalizácia kapitálovej štruktúry podniku [elektronický zdroj]. 1. vyd. Frankfurt am Main: Neowiss - Europäischer Wissenschaftsverlag, 2017. e-book

$4 \quad$ Štetka, P. - Šlosár, R. - Vrtíková, K. (2015): Informačný mechanizmus difúzie produktových inovácií naprieč európskymi trhmi. In Aktuálne problémy podnikovej sféry 2015. Bratislava: Vydavatel'stvo EKONÓM, 2015 
effort of the company. To make the company innovative, just a good idea is not enough, there must be of "a combination of good ideas, motivated employees and an intuitive understanding of what customers want." ${ }^{5}$ The company needs to innovate not only the products offered, but also to innovate itself, its business strategy and the space in which it operates. From this point of view, the assessment of innovation can be a highly challenging task. Approaches to evaluating the success of innovation consider the objective and the focus of innovation, also the objective and focus of the decision-making process for which the information on the success of innovation has been developed. The decision-making process may involve the initiation or continuation of innovation, possibly launching innovation on the market, the method of evaluating the success of innovation will then depend on the stage where the innovation is. In the initial phase of the innovation process, the assessment criteria will be rather technical, respectively, will have a non-financial nature, which according to the measure of compliance testify on whether the innovation is likely to be profitable after its completion ${ }^{6}$. While dealing with innovative projects being updated with information on the possibilities of the market utilization of innovation, on eligible costs, or on production processes, the share and importance of purely economic indicators with the increasing degree of approximation will grow to the moment of realization of innovation on the market. One approach to evaluating an innovation is the definition of success factors and assessment of level of its achievement. For instance, Hernardo and Szymanski ${ }^{7}$ divided success factors to cover all aspects of the innovation into 4 main groups, in which the innovation should be successful, namely: product characteristics (superiority over competing products, a series of innovation and resource capacity), strategic factors (technological potential and marketing synergy), procedural characteristics (market and customer orientation) and market characteristics. Trommsdorff and Steinhoff ${ }^{8}$ developed the so-called CIA analysis - Competitive Innovation Advantage, which emphasizes that not only the technical solution for the success of a product innovation is important, but also the advantage of a new product for the user.

Considering that innovation has usually a capital nature, another approach to assessing the success of innovation is the use of techniques and methods of assessing the effectiveness of a company investment (NPV, IRR, payback period). Based on the objective of innovation that can be to maintain or increase the performance of the business entity, success of innovations can be evaluated based on the innovation impact on the financial results of the company. The method of evaluation of the innovation will mainly be used for evaluating the innovation

Porter, M. (1990): The Competitive Advantage of Nations. New York: Free Press, 1990. 875 s. Synek, M. a kolektív (2011): Manažérska ekonomika. Praha: Grada, 2011. $471 \mathrm{s.}$

Henard, D.H. - Szymanski, D.M. (2001): Why some new products are more successful than others. JMR, Journal of Marketing Research; Aug 2001; 38, 3; ABI/INFORM Global pg. 362

8 Trommsdorff, V. - Steinhoff, F. (2009): Marketing inovací. Praha: C.H. Beck, 2009. 291 s.

Vol. 16, № 3, 2019: 83-94 
after its launch to obtain information on the real impact of innovation on business results. They are used for deciding on, for instance, the further necessary corrections of the implemented innovation, or the initiation of an innovation and serve to create a knowledge base for the assessment of new innovations.

The paper is focused on mapping the potential impact of innovation of enterprises on their economic performance at the level of the whole sector and the definition of economic indicators that show some dependence on innovation. The performance of the industry will be assessed based on the development of the mean values of selected ratios (CRIB) considering the innovative activities of industry in Slovakia (Statistical Office of the SR, 2008-2010 , 2010-2012 ${ }^{10}$, 2012-2014 ${ }^{11}$ ). (Until we submitted our article we did not know the results for the period 2014-2016. To keep the continuity of the innovation indicators, we have compiled data for these years from other surveys.) The methodology of the statistical survey on innovation was worked out within the framework of the process of implementation of the statistical methodology of the EU member states. It was based on the OSLO manual methodology of OECD/Eurostat ${ }^{12}$ and it was harmonized with the Fifth Community Innovation Survey (CIS 2010) of the EU member states. The set of reporting units was created from the official statistical business register by combination on an exhaustive survey and a stratified sample survey in particular branches of economic activity.

\section{Results}

To select the indicators that could reflect the impact of the development of innovative activity of industrial enterprises, we have evaluated both the development of overall innovation and different types of innovation, and we have focused on the nature of the expenditures on innovation. Based on the surveys of the Statistical Office of the SR, several companies involved in innovation activities have slightly upward trend, on the contrary, their share have a downward trend in the total number of enterprises. Most innovations are implemented at industrial and service enterprises. In comparison with mean we have chosen the industrial enterprises, whose share in the total number of enterprises declined, it is still the highest, though

\footnotetext{
$9 \quad$ Štatistický úrad Slovenskej republiky (2012): Inovačná aktivita v Slovenskej republike 20082010. Bratislava: ŠÚ SR, 2010. 270 s.

10 Štatistický úrad Slovenskej republiky, (2014). Inovačná aktivita v Slovenskej republike 20102012. Bratislava: ŠÚ SR, 2014. 261 s.

11 Štatistický úrad Slovenskej republiky (2016): Inovačná aktivita v Slovenskej republike 20122014. Bratislava: ŠÚ SR (2016) 246 s.

12 OECD (2005): Oslo Manuál: Guidelines for Collecting and Interpreting Innovation Data, 3rd Edition, The Measurement of Scientific and Technological Activities, Paris: OECD Publishing, 2005. 166 s.
} 
Figure 1: The share of enterprises with innovation activity

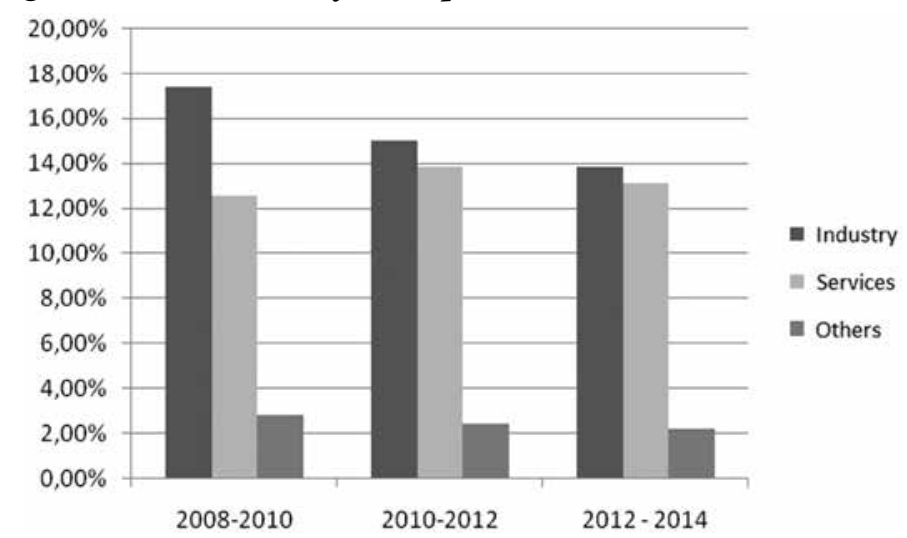

Source: Own processing based on the report of the Statistical Office of the SR

In terms of the nature of innovation, the technological innovation is prevalent in industrial enterprises. Non-technological innovation recorded an increase in service enterprises.

\begin{tabular}{|c|c|c|c|c|c|c|}
\hline & \multicolumn{2}{|c|}{ 2008-2010 } & \multicolumn{2}{|c|}{ 2010-2012 } & \multicolumn{2}{|c|}{$2012-2014$} \\
\hline & Industry & Total & Industry & Total & Industry & Total \\
\hline $\begin{array}{l}\text { All kinds of innovation } \\
\text { activities }\end{array}$ & 1224 & 2306 & 1197 & 2496 & 1250 & 2632 \\
\hline Technological innovation & 1029 & 1769 & 723 & 1393 & 867 & 1612 \\
\hline Non-technological innovation & 195 & 537 & 474 & 1103 & 383 & 1020 \\
\hline $\begin{array}{l}\text { Enterprises with no innovation } \\
\text { activities }\end{array}$ & 2185 & 4727 & 2492 & 5481 & 2596 & 6398 \\
\hline
\end{tabular}

Source: Own processing based on the report of the Statistical Office of the SR

The predominance of technological innovation is confirmed by the survey of the SIEA organization, conducted in 2012 on a sample of 195 innovative companies in the Slovak Republic ${ }^{13}$. Even in this survey it has been confirmed that the innovating enterprises implemented mainly two types of innovation: "new and significantly altered goods and services" (38.2\% of total responses) and "new or significant changes in the method of the production or providing services" (25\% of total responses). The minimum innovations, $14 \%$ of the total responses, concerned "significant change in organization of the enterprise." Considering the total number of activities, a not insignificant part of respondents (4\%) implemented none of the above innovation activities.

$13 \quad$ Balog, M. and kol.(2013): Inovatívne Slovensko - východiská a výzvy. Bratislava: Slovenská inovačná a energetická agentúra, 2013. 
To select ratios, which could influence the implemented innovation, it is necessary to examine the types of the innovations in the industry. At a more detailed analysis of the development of different types of technological innovation, it is evident that particularly the combination of process and product innovations prevails. In the last reporting period, it is possible to observe a slight increase in product innovations in industrial plants, on the contrary the innovation activity in processes has been slightly increasing at the service enterprises.

Figure 2: Types of innovations in industry

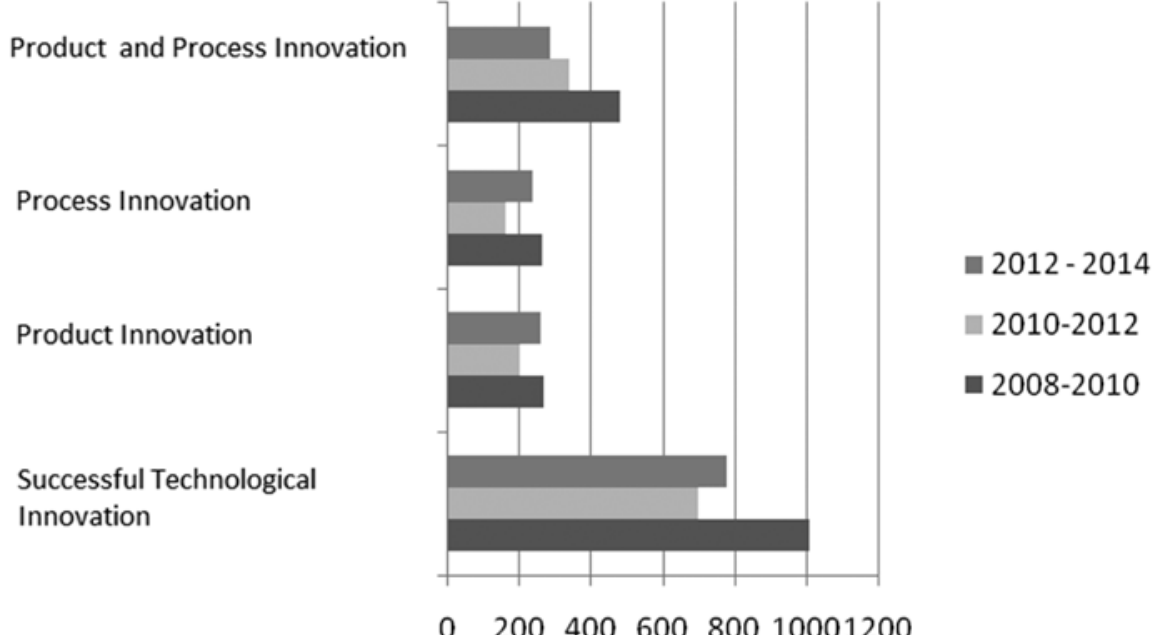

Source: Own processing based on the report of the Statistical Office of the SR

Based on the above, we can conclude that between 2010 and 2012 the proportion of successfully implemented technological innovations significantly decreased. In the following period, their proportion has slightly grown. There are several reasons for the decline of enterprise innovation activities. Based on the survey of Balog ${ }^{14}$, the crucial factors limiting the development of innovations are:

- lack of resources in the enterprise, or

- high expenditure on innovation.

Innovation expenditures include all expenditures related to scientific, technological and commercial steps leading to the establishment of innovation. The expenditures for the procurement of machinery and equipment largely contribute on overall innovation expenditures. Although this volume of expenditures on total expenditure in innovation declines, in the period 2012-2014 they dropped almost in half, they remain most substantial component of expenditure.

$14 \quad$ Ibid 
Figure 3: The structure of expenditure on innovation activities in industrial enterprises

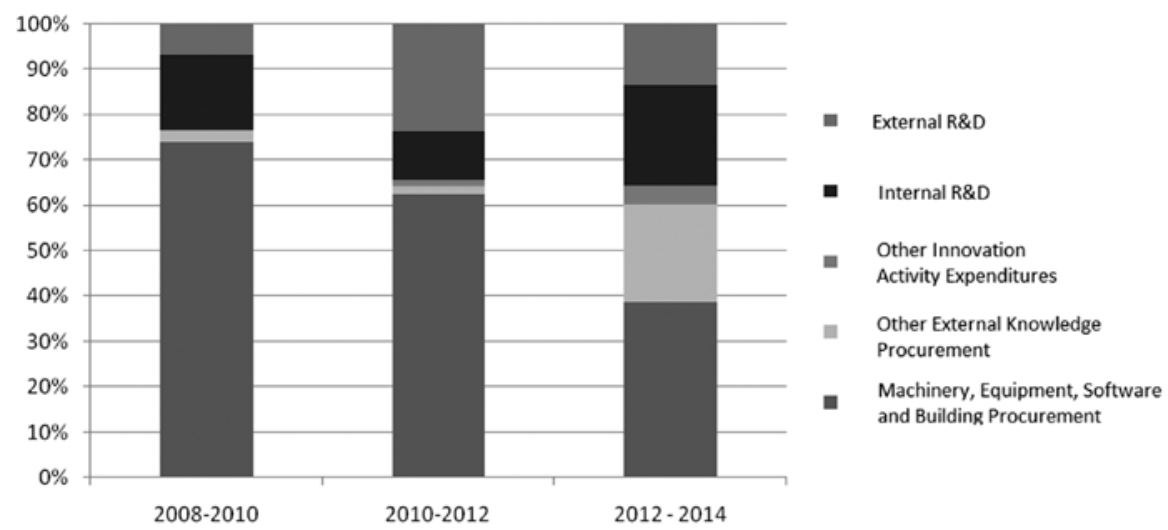

Source: Own processing based on the report of the Statistical Office of the SR

The structure of expenditures has changed in favour of expenditures on internal research and development, which doubled in favour of expenditure on acquisition of other external knowledge that increased several times in 20122014. These expenditures are reflected in companies mainly in depreciation and consumption of materials and services.

To assess the impact of innovation activities in industrial enterprises based on the data, we have chosen the following indicators:

- $\mathrm{ROS}$ - the indicator reflects the proportionality of changes in profit and sales,

- \% value added of total turnover - the indicator reflects the proportionality of changes in value added to the changes in sales; it is influenced by the size of the cost of consumption of materials and services,

- \% EBITDA of total turnover - the indicator reflects the proportionality of changes in earnings before taxes, interest and depreciation to the changes in revenues; it is affected by the structure of financing (funding) and the size of depreciation,

- $\mathrm{ROA}$ - the indicator reflects the proportionality of changes in earnings (EBIT) to the change of the asset,

- Total assets turnover - indicator reflects the proportionality of changes in revenue to the changes in assets that have been affected by the size of expenditure on procurement of machinery, equipment, software and buildings.

Mean values of indicators are divided into lower quartile (DK), median (Me) and upper quartile (HK), and we can assume that the enterprises with innovation activity are among at least $50 \%$ of the best companies. 
Figure 4: ROS development in industry in 2008 -

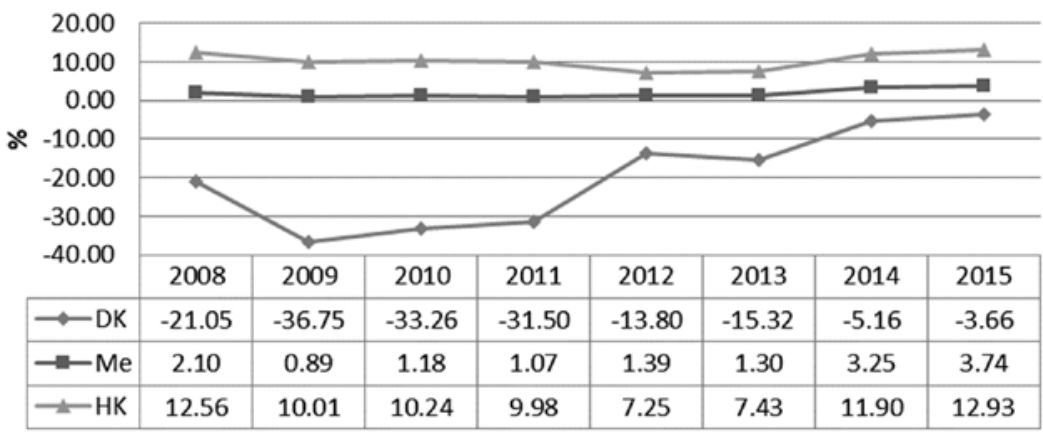

Source: Own processing based on the mean values of selected ratios CRIB

ROS tends to increase. The indicator declined in 2012 to 2013. Considering the development of innovative activities, which were the lowest in the period 2010 to 2012, we can conclude, that innovation activities may affect ROS with a certain time lag.

Figure 5: The \% value added of total turnover and the \% EBITDA of total turnover development in industry in 2008 - 2015
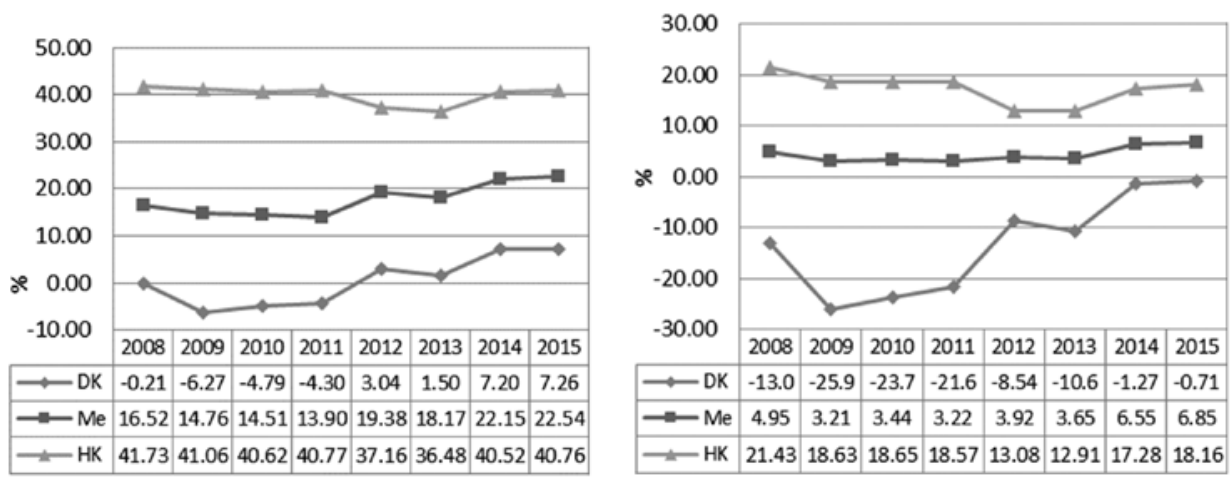

Source: Own processing based on the mean values of selected ratios CRIB

Both the \% of value added of total turnover and the \% EBITDA of total turnover show the contradictory development of the best and the worst companies. The upper quartile enterprises have been in decline in the value of both indicators in 2012 and 2013, the \% EBITDA of total turnover even in 2014 achieved significantly lower level compared to the 2011. Enterprises in the other quartiles have an upward trend, and it recorded a slight decrease only in 2013. The decline between 2012 - 2014 in the top quartile may result from changes in the of innovation structure of expenditure in the certain period, which affected expenditures of enterprises. 
Figure 6: ROA and Total assets turnover development in industry in 2008 - 2015
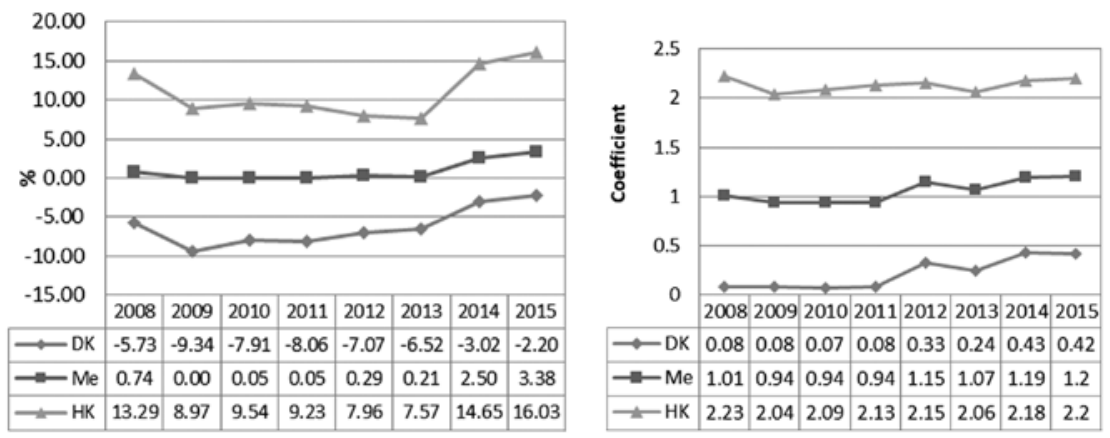

Source: Own processing based on the mean values of selected ratios CRIB

Both indicators are developed contrarily in the upper quartile, median and lower quartile. There are the lowest values of ROA at the top quartile is in 2012 and 2013, as well as ROS, which were affected mainly by falling profits. Total assets turnover was the lowest in 2013, which could influence the reduction of sales with respect to the reduction of innovation activities in the previous period.

\section{Conclusion}

The paper focused on mapping the potential impact of innovations of enterprises in their economic performance at the level of the whole sector. We have chosen a method for assessing the success of innovations because of the need to quantify the impact of innovations on company performance, which is one of the innovation objectives. Businesses expect increase competitiveness, growth, performance, or maintaining existing performance from implementing the innovations. From this perspective, an innovation for business means investment, and like any investment, it should bring the company its economic improvement. The expected effects may be: the growth, maintaining the market share, cost reduction, production efficiency improvement, risk reduction, working conditions improvement, turnover reduction, and so on. From this perspective, it is difficult to quantify the individual effects of innovations and consider innovation as an investment. Nevertheless, it is expected that innovation will affect the overall financial situation and its impact can be seen in the development of the absolute and ratio indicators of the financial analysis.

The article was focused on the comparison of statistical processed reports on innovative activities of enterprises in various industries developed at the macro level with the development of the mean values of selected financial indicators in the surveyed sectors CRIF-Slovak Credit Bureau, Ltd.) in order to identify the impact of innovation on company performance. Based on the results of the 
comparison, we defined the determinants showing the dependence of innovation activities..

Based on the applied comparison of the development of innovation and development of the secondary value ratios mapping an economic situation, we can conclude that ROS indicators show a certain dependency, the \% value added of total turnover, the \% EBITDA of total turnover, the ROA and the total assets turnover.

\section{Literature}

- Balog, M. and kol.(2013): Inovatívne Slovensko - východiská a výzvy. Bratislava: Slovenská inovačná a energetická agentúra, 2013. ISBN 978-80-8823-55-1

- Henard, D.H. - Szymanski, D.M. (2001): Why some new products are more successful than others. JMR, Journal of Marketing Research; Aug 2001; 38, 3; ABI/INFORM Global pg. 362

- Markovič, P. - Rybárová, D. (2017): Bod indiferencie a optimalizácia kapitálovej štruktúry podniku [elektronický zdroj]. 1. vyd. Frankfurt am Main: Neowiss Europäischer Wissenschaftsverlag, 2017. e-book ISBN 978-3-945484-16-6.

- OECD (2005): Oslo Manuál: Guidelines for Collecting and Interpreting Innovation Data, 3rd Edition, The Measurement of Scientific and Technological Activities, Paris: OECD Publishing, 2005. 166 s. ISBN 978-92-6401-308-3

- Porter, M. (1990): The Competitive Advantage of Nations. New York: Free Press, 1990. 875 s. ISBN 0029253616

- Synek, M. a kolektív (2011): Manažérska ekonomika. Praha: Grada, 2011. 471 s. ISBN 9788024734941.

- Štatistický úrad Slovenskej republiky (2016): Inovačná aktivita v Slovenskej republike 2012-2014. Bratislava: ŠÚ SR (2016) 246 s. ISBN 978-80-8121-521-6

- Štatistický úrad Slovenskej republiky, (2014). Inovačná aktivita v Slovenskej republike 2010-2012. Bratislava: ŠÚ SR, 2014. 261 s. ISBN 978-80-8121-334-2

- Štatistický úrad Slovenskej republiky (2012): Inovačná aktivita v Slovenskej republike 2008-2010. Bratislava: ŠÚ SR, 2010. 270 s., ISBN 978-80-8121-156-0

- Štetka, P. - Šlosár, R. - Vrtíková, K. (2015): Informačný mechanizmus difúzie produktových inovácií naprieč európskymi trhmi. In Aktuálne problémy podnikovej sféry 2015: [recenzovaný] zborník vedeckých prác. Bratislava: Vydavatel'stvo EKONÓM, 2015. - ISBN 978-80-225-4077-3. - S. 671-678 CD-ROM.

- Trommsdorff, V. - Steinhoff, F. (2009): Marketing inovací. Praha: C.H. Beck, 2009. 291 s. ISBN 978-80-7400-092-8. 


\section{ODNOS IZMEĐU INOVACIJE I POSLOVNOG UČINKA}

Analiza stručne literature pokazuje da mnoga preduzeća mere performanse inovacija na osnovu kombinacije ulaznih i izlaznih pokazatelja. Rezultati poređenja potvrdili su da postoji mnogo koncepata u merenju performansi inovacija, ali oni nisu konzistentni. U naučnoj praksi postoje i mišljenja da su studije o pokazateljima merenja performansi inovacija neadekvatne. Rezultati pokazuju da je većina indikatora orijentisana na ulaz a samo nekoliko pokazatelja je orijentisano na izlaz. Preduzeća se suočavaju sa poteškoćama kada uspostavljaju jasan odnos između poslovne inovacije i njenog učinka. Kada se meri uspešnost inovacija, postoji ozbiljan problem sa značajnim kašnjenjem prednosti inovacija i složenošću izolacije i uloge inovacije od drugih poslovnih aktivnosti u odnosu na ukupne performanse. Merenje inovativnih poslovnih performansi može se postići finansijskim pokazateljima kao što su ROE, ROI i nefinansijskim pokazateljima, poput broja novih ideja, proizvoda i tako dalje. Ovaj rad ima za cilj da uporedi razvoj inovacija u izabranom sektoru i razvoj finansijskih pokazatelja ovog sektora za identifikaciju pokazatelja čiji razvoj najviše odgovara razvoju inovacije.

Ključne reči: konkurentnost, evaluacija, inovacije, performanse 